\title{
Eating in the City: A Review of the Literature on Food Insecurity and Indigenous People Living in Urban Spaces
}

\author{
Kelly Skinner ${ }^{1, *}$, Erin Pratley ${ }^{2}$ and Kristin Burnett ${ }^{3}$ \\ 1 School of Public Health and Health Systems, University of Waterloo, Waterloo, ON N2L3G1, Canada \\ 2 Independent Scholar, Killara, New South Wales 2071, Australia; erinpratley@gmail.com \\ 3 Department of Indigenous Learning, Lakehead University, Thunder Bay, ON P7B5E1, Canada; \\ kburnett@lakeheadu.ca \\ * Correspondence: kskinner@uwaterloo.ca; Tel.: +1-519-888-4567 (ext. 38164) \\ Academic Editor: Gregor Wolbring
}

Received: 2 February 2016; Accepted: 15 March 2016; Published: 24 March 2016

\begin{abstract}
Indigenous people often occupy different overlapping or co-existing food environments that include market-based foods, land and water based foods, and combinations of the two. Studying these food environments is complicated by the cultural and geographic diversity of Indigenous people and the effects of colonialism, land dispossession, relocation and forced settlement on static reserves, and increasing migration to urban areas. We conducted a scoping study of food insecurity and Indigenous peoples living in urban spaces in Canada, the United States, and Australia. The 16 studies reviewed showed that food insecurity among urban Indigenous populations is an issue in all three nations. Findings highlight both the variety of experiences of urban Indigenous peoples within and across the three nations, and the commonalities of these experiences.
\end{abstract}

Keywords: food insecurity; Indigenous people; Canada; United States; Australia

\section{Introduction}

Indigenous food security in remote, rural, and on-reserve populations has been well studied in Canada, the United States, and Australia [1-7]. Studies identify colonialism [8]; barriers to accessing traditional foods (e.g., [1,2,9,10]); dietary transition (e.g., [11,12]); diet and health (e.g., [13,14]]; food and livelihood change (e.g., [15]); and the costs of commercial or market based foods (e.g., [16,17]) as the major causes of food insecurity. In these three nations, a large percentage of Indigenous peoples live in urban centres: 53\% in Canada [18]; 71\% in the United States [19], and 57\% in cities and inner regional areas of Australia [20]. Yet, less attention has been paid to food security among urban Indigenous people, even though some of the issues facing urban Indigenous populations are unique from those confronting rural and reserve Indigenous populations. According to Hill and Cooke [21], urban Indigenous populations differ from rural and remote populations because they tend to be more culturally diverse; the community consists of both individuals new to urban environments and those who have lived in an urban location for years or generations; and while some individuals have close connections to their home community (and may migrate back and forth), others have stronger ties to an urban social-network. This article discusses the results of a scoping study to assess the breadth and depth of knowledge on food insecurity for Indigenous people living in urban spaces in order to identify gaps in the literature and potential avenues for further inquiry.

Although Indigenous peoples in Canada, the United States, and Australia possess distinct and unique histories, circumstances, beliefs, and diets, there are some common characteristics that allow us to compare the experiences of Indigenous peoples living in urban spaces. As noted by 
Cooke et al. [22], Canada, the United States, and Australia are industrialized and developed nations that have comparable colonial origins and are often used "... as natural comparators in terms of Indigenous well-being..." because "these countries consistently place near the top of the United Nations Development Programme's Human Development Index (HDI) rankings, yet all have minority Indigenous populations with much poorer health and social conditions than their non-Indigenous compatriots". Various studies have compared some or all of these nations when examining Indigenous issues, including: social determinants of health [23]; rural food security [24]; culturally-competent health care practices [25]; lack of Indigenous participation in health research [26]; and disproportionate rates of urban homelessness for Indigenous peoples [27], yet there has not been a review of urban Indigenous food security that compares Indigenous experiences in Canada, the United States, and Australia. The Indigenous populations living in these three settler states face many of the same structural social, economic, and political inequalities that make them disproportionately vulnerable to food insecurity.

The term food insecurity or food insecure has, over the last several decades, come to be one of the most widely used assessment tools to measure "food deprivation", broadly defined. Food insecurity is the lack of access to healthy affordable food. The use of the term food insecure is purposeful and moves away from the binary and false notion that people are either hungry or not hungry. It is also a term that incorporates the long and short-term strategies people (households and communities) draw on to avoid hunger or food deprivation. In this review, we use the definition adopted by the United Nations, World Health Organization, and 183 nations: food security exists "when all people, at all times, have physical and economic access to sufficient, safe and nutritious food to meet their dietary needs and food preferences for an active and healthy life" [28].

We further complicate this definition by arguing it is necessary to incorporate race, ethnicity, and culture when exploring food security. Culture is a key determinant of Indigenous diets [29-32], including the types of food and the practices of procurement, preparation, sharing and eating. For instance, a study of the role of traditional foods in the Wapekeka and Kasabonika First Nations found that "wild food harvesting remains an important feature of community life", is "incorporated into family social practices", and the preparation of game is an essential moment of intergenerational teaching and sharing [3]. In Australia, Bussey et al. [24] found that traditional food (also called "bush tucker" in Australia and "country food" in Canada) plays a significant role in ensuring food security for remote and rural Indigenous peoples, and a recent review of Indigenous food security in the United States concluded that "access to healthy and/or traditional foods as the most significant barrier to Native American food security" [33] (p. 690). Thus, traditional food including food sharing, food skills, and preferences, is a key component of cultural food security for Indigenous peoples.

Focusing on urban environments specifically acknowledges that place matters when understanding food security. The influence that the "food environment" has on physical and dietary activity has been well documented [34]. According to a recent report [35] released by Health Canada, the food environment includes a wide range of factors such as: geographic food access (where and what kinds of stores are available in proximity to you); food availability (the kinds of foods that are obtainable in someone's community); food affordability (refers to the cost of food in a particular based on the standardized pricing tool for a household); and food quality (refers to subjective assessments of food quality and the shopping experience). Urban Indigenous people face different challenges and have food environments that are unique to their rural, remote, and on-reserve counterparts, and currently the literature does not reflect the experiences of urban Indigenous populations.

\section{Rates of Food Insecurity among Indigenous Populations}

In Canada, a report on Household Food Insecurity in 2012 revealed that, in addition to an array of other characteristics like income, people who lived in urban areas had higher rates of food insecurity than those living in rural areas [36]. In countries like Canada and the United States, urban/rural spaces are further divided by reserves and reservations, respectively, and in Australia into reserves and stations. Studies show that Indigenous people who live on reserves face disproportionately high 
rates of food insecurity [1,37]. A report recently released by the First Nations Food Nutrition and Environment Study [37] looked at seven larger First Nations communities in Northern Ontario and reported $52 \%$ of households as food insecure. Rates of food insecurity in some First Nations households in Northern Ontario households are even higher. For example, a discrete study of food insecurity in Fort Albany First Nation (a fly in community located along west coast of James Bay) reported that $70 \%$ of households were food insecure [1]. While slightly lower, Indigenous people in metropolitan areas in Canada face similar challenges; in 2012, 28\% of off-reserve Indigenous households compared to $13 \%$ of non-Indigenous households were food insecure [36]. Between 1961 and 2006 the Indigenous population living in urban areas in Canada increased from 13\% of the total Indigenous population to $53 \%$ [38]. The most recent numbers show that, in Ontario, 63\% of Indigenous people who are federally registered as status Indians live off reserve and reside in metropolitan areas [39].

For the United States food security statistics specifically for Native Americans were difficult to find. For example, the United States has conducted few studies that focus explicitly on Native Americans but significant data exists on the relationship between food security and space for African Americans and Latinos/Hispanics [40-46]. In a 2013 study that looked at counties with high populations of visible minorities, they found that Native American food insecurity ranged anywhere from $20 \%$ to $28 \%$, while the general level of food insecurity for the entire United States is 14\% [47]. It is unclear whether or not this is a true reflection of food insecurity for urban dwelling Native Americans. This represents a huge gap in the literature. Between 1960 and 1970 the population of Native Americans living in cities and towns doubled, expedited by government relocation programs and the Termination Act of 1953 [48].

Australia is largely regarded as a food-secure nation with only about $5 \%-8 \%$ of the general population suffering from food insecurity [49]. However, those numbers change dramatically for the Indigenous population. Like Canada, the majority of Indigenous people in Australia, nearly 58\%, live in urban areas. Food insecurity among Indigenous people living in the capital cities of Australia is $32 \%$, in regional areas it is $43 \%$, and in remote areas it is $25 \%$ [50]. Thus, for Indigenous people in Australia the rate of food insecurity on average is four to five times higher than the non-Indigenous population [50]. Like Canada and the United States, in the post WWII period, Indigenous people in Australia increasingly migrated to urban areas through forced government relocations or in the search for employment, education, and better access to health care and social services.

\section{Methodology}

The scoping review (as defined by the Canadian Institutes of Health Research-CIHR) was conducted of online peer-reviewed journal articles. A scoping review was chosen for this topic, because both "the potentially relevant literature is thought to be especially vast and diverse (varying by method, theoretical orientation or discipline)" and "there is suspicion that not enough literature exists" [51]. The methods for the scoping review were adapted from the first five stages of the scoping framework outlined by Arksey and O'Malley [52] and refined by Levac et al. [53], omitting the sixth optional stage. After determining the research question-What is the breadth and depth of knowledge on urban Indigenous food security in the chosen countries?-We conducted a search that included peer-reviewed journal articles from 1997 to August 2015. Following the protocol used by Bussey [24], articles prior to 1997 were excluded, as the internationally agreed upon definition for food security noted above was established in the fall of 1996.

The list of databases searched and search terms are included in Figure 1. Keywords and combinations of keywords in four different areas-food security/urban/Indigenous/country location-were used. Our initial searches included New Zealand, as we originally had intended to include the nation in the review. However, we chose to exclude New Zealand from the review after no articles were found that matched our search criteria. In the case of the United States, where the initial search returned few articles, a search of all tribes with a population over 100,000 [19] was conducted, with the specific tribe name searched along with the search term "food", in an attempt to capture more articles. A hand search was conducted of relevant non-indexed journals, individual authors with 
prominent work in this field (see Figure 1), and from the reference lists of articles that were chosen. All articles were initially screened by title and abstract. Articles that were not excluded based on the initial screen were selected for full article review, where they were examined for adherence to the specific inclusion and exclusion criteria.

\begin{tabular}{|c|c|c|c|c|c|}
\hline Food Security & Urban & Indigenous & Country & Inclusion Criteria & Exclusion Criteria \\
\hline $\begin{array}{l}\text { "food security" } \\
\text { "food insecurity" } \\
\text { hunger } \\
\text { "traditional food*" } \\
\text { "traditional diet" } \\
\text { "bush food"" } \\
\text { "country food*" } \\
\text { food }\end{array}$ & $\begin{array}{l}\text { urban } \\
\text { city } \\
\text { cities } \\
\text { metropol* } \\
\text { town }\end{array}$ & $\begin{array}{l}\text { Aborigin* } \\
\text { Indigen* } \\
\text { "First Nation" } \\
\text { Inuit } \\
\text { "Alaskan Indian" } \\
\text { Métis } \\
\text { Apache } \\
\text { Cherokee } \\
\text { Chippewa } \\
\text { Choctaw } \\
\text { "Mexican American Indian" } \\
\text { "Native American" } \\
\text { "American Indian" } \\
\text { Maori } \\
\text { Navajo } \\
\text { Sioux }\end{array}$ & $\begin{array}{l}\text { Canada } \\
\text { United States } \\
\text { Australia }\end{array}$ & \multirow[t]{5}{*}{$\begin{array}{l}\text {-Location was } \\
\text { urban } \\
\text {-Within one (or } \\
\text { more) of the } 3 \\
\text { countries } \\
\text {-Minimum one } \\
\text { paragraph on urban } \\
\text { Indigenous Food } \\
\text { Security }\end{array}$} & \multirow{5}{*}{$\begin{array}{l}\text {-Only statistical } \\
\text { information (chart or } \\
\text { graph) } \\
\text {-Studies on*: } \\
\quad \text { - diabetes } \\
-\quad \text { obesity } \\
\quad \text { health } \\
\quad \text { promotion } \\
\quad \text { tobacco } \\
\quad \text { nutrition } \\
\text { *unless there was a } \\
\text { focus on food security } \\
\text { as it relates to these } \\
\text { topics. } \\
\text {-Two articles from the } \\
\text { same study (most } \\
\text { relevant one was } \\
\text { chosen) } \\
\text {-Regional and national } \\
\text { level studies that have } \\
\text { not been published in } \\
\text { peer-reviewed journals } \\
\text {-Studies that did not } \\
\text { distinguish urban } \\
\text { within off-reserve data } \\
\text { sources }\end{array}$} \\
\hline \multicolumn{4}{|c|}{ Databases Searched } & & \\
\hline \multicolumn{4}{|c|}{$\begin{array}{l}\text { Web of Science } \\
\text { ERIC } \\
\text { Social Sciences Abstracts } \\
\text { CINAHL } \\
\text { PubMed }\end{array}$} & & \\
\hline \multicolumn{4}{|c|}{ Hand Search of Journals, Authors, and Reference lists } & & \\
\hline $\begin{array}{l}\text { Journals: American } \\
\text { Australian Indigenou } \\
\text { Authors: Karen Ada } \\
\text { Loring } \\
\text { Reference lists of art }\end{array}$ & Jaime Cidro; B & $\begin{array}{l}\text { ylliott; Wendy Foley; Jame } \\
\text { on criteria and passing the exc }\end{array}$ & $\begin{array}{l}\text { ity Psychology; } \\
\text { Pimatisiwin } \\
\text { rd; Philip A. } \\
\text { n criteria }\end{array}$ & & \\
\hline
\end{tabular}

Figure 1. Search protocol and inclusion and exclusion criteria.

We borrow John Weeks' definition of urban to mean "a placed-based characteristic that incorporates elements of population density, social and economic organization, and the transformation of the natural environment into a built environment" [54] (p. 34).

While no universal definition of Indigenous exists, we draw on the United Nations guidelines [55], to include peoples with the following traits: those who self-identify as Indigenous and are accepted by others as belonging to a community; have a historical continuity with a pre-colonial society; have distinct social, economic, or political system; have distinct language, culture, and beliefs. Although not explicitly stated in the United Nations guidelines, it is generally recognized that traditional foods and diet are important parts of Indigenous culture and beliefs [31,32,56-58].

\subsection{Inclusion/Exclusion Criteria}

A full list of inclusion and exclusion criteria are summarized in Figure 1. Articles that dealt with urban Indigenous populations in Canada, the United States, and Australia were included in the search. The article had to have at least one paragraph that discussed an aspect of urban Indigenous food security and included some primary research. Since the definition of urban is not standardized across the three countries under review, any article that self-identified as urban (including city, metropolitan, suburban) or made mention of a specific urban location (e.g., Vancouver, Fairbanks, Melbourne) was included.

Articles that focused on rural, remote, or on-reserve locations exclusively were excluded, as was work that looked at off-reserve, but not specifically urban, populations. Work that took a regional or national level approach to Indigenous food security was excluded, unless there was at least one paragraph discussing the urban context. Likewise, work that focused on broader urban food security 
(including statistics that had a category for Indigenous people) was excluded, unless it included at least one paragraph on Indigenous food security. Studies that were focused solely on diabetes, obesity, tobacco, health promotion, nutrient uptake, or housing were also excluded from the review. Work that was framed within the discussion of one of the above noted issues but with a focus on an aspect of food security was included.

\subsection{Content Analysis and Synthesis}

From the articles that met the inclusion criteria, qualitative content analysis was conducted. The range of methodologies found (including ethnographic, mixed methods, and quantitative surveys) precluded any systematic meta-synthesis. Instead, a narrative synthesis was conducted [59], following an iterative process. The articles were each read in their entirety, and topics that related to urban food security of Indigenous populations were identified in each article and coded manually. A second reading of each article was conducted once each had been through an initial coding, both to extract additional data and to group topics into major themes. Topics were then synthesized and discussed in relation to each other-highlighting the similarities and differences across findings, and identifying the gaps in knowledge.

\section{Results}

The literature search resulted in 16 articles, with the following geographic focus: nine in Canada, five in Australia, and two in the United States. This was lower than the initial projected number of articles, and reflects the paucity of literature on food security with Indigenous populations living in urban locations across these three countries. Thirteen articles are dated from 2010 on, and four of these were published in 2014 and 2015, indicating that urban Indigenous food security is becoming increasingly recognized as a concern. Table 1 outlines, for each article, the authors; country location; methodology; and main purpose of the study. Of the articles, all but two used some qualitative methods consisting of: interviews $(n=7)$, observation $(n=3)$, focus groups $(n=2)$, photovoice $(n=2)$, and story/dialogue $(n=1)$. Three articles used surveys and quantitative analysis.

Table 1. Summary of articles included in the review.

\begin{tabular}{|c|c|c|c|}
\hline Author/Date & Country & Purpose & Methods \\
\hline Abbott, 2010 [60] & Australia & $\begin{array}{l}\text { "... presents findings from an evaluation of the } \\
\text { 'cooking course for Indigenous people at risk for } \\
\text { diabetes' ... as to the factors that impacted on } \\
\text { participants applying the knowledge and skills } \\
\text { acquired at the course to their daily lives." (p. 34)* }\end{array}$ & $\begin{array}{l}\text { Semi-structured } \\
\text { interviews }\end{array}$ \\
\hline $\begin{array}{l}\text { Adams et al., } \\
2013 \text { [61] }\end{array}$ & Australia & $\begin{array}{l}\text { "... to work collaboratively with an urban } \\
\text { Aboriginal community to understand the } \\
\text { meanings of food and food insecurity and use } \\
\text { action research to strengthen responses to this } \\
\text { issue." (p. 498) }\end{array}$ & Photovoice \\
\hline $\begin{array}{l}\text { Brown et al., } \\
2008 \text { [62] }\end{array}$ & Canada & $\begin{array}{l}\text { "... to explore the eating experiences and use of } \\
\text { traditional foods of Aboriginal adults who had } \\
\text { moved to an urban centre from a reserve } \\
\text { community." (p. 2) }\end{array}$ & $\begin{array}{l}\text { Questionnaires } \\
\text { Focus groups (using } \\
\text { concept mapping) }\end{array}$ \\
\hline $\begin{array}{l}\text { Cidro et al., } \\
2015 \text { [63] }\end{array}$ & Canada & $\begin{array}{l}\text { "... discusses the results of preliminary research } \\
\text { conducted which explored the experiences and } \\
\text { meanings associated with Indigenous cultural food } \\
\text { for Indigenous people living in urban } \\
\text { communities." (p. 5) }\end{array}$ & $\begin{array}{l}\text { Focus groups and } \\
\text { individual interviews }\end{array}$ \\
\hline $\begin{array}{l}\text { Cuesta-Briand et al., } \\
2012 \text { [64] }\end{array}$ & Australia & $\begin{array}{l}\text { "... focuses on food security issues experienced } \\
\text { by low-income earners living with type } 2 \text { diabetes } \\
\text { in Perth, Western Australia." (p. 683) }\end{array}$ & $\begin{array}{l}\text { Focus groups } \\
\text { In-depth interviews }\end{array}$ \\
\hline
\end{tabular}


Table 1. Cont.

\begin{tabular}{|c|c|c|c|}
\hline Author/Date & Country & Purpose & Methods \\
\hline $\begin{array}{l}\text { Dillinger et al., } \\
\quad 1999 \text { [65] }\end{array}$ & United States & $\begin{array}{l}\text { "... examines the roles of supplemental food } \\
\text { programs in two Native American populations of } \\
\text { northern California, one rural and the other urban." } \\
\text { (p. 174) }\end{array}$ & Survey \\
\hline $\begin{array}{l}\text { Elliott et al., } \\
2012[66]\end{array}$ & Canada & $\begin{array}{l}\text { "... to assess the challenges and solutions to } \\
\text { accessing traditional Aboriginal foods in the urban } \\
\text { context of Vancouver, BC." (p. 2) }\end{array}$ & $\begin{array}{l}\text { Modified } \\
\text { story/dialogue }\end{array}$ \\
\hline $\begin{array}{l}\text { Fazzino and Loring, } \\
2009 \text { [67] }\end{array}$ & United States & $\begin{array}{l}\text { "... examine the so-called 'food crisis' in rural } \\
\text { and urban Alaska ... as a process of the } \\
\text { cumulative effects of increasing prices of fuel, } \\
\text { climate change and its impacts on peoples' ability } \\
\text { to harvest wild, 'country' foods, in-creasing prices } \\
\text { of store-bought foods (esp. in rural Alaska), and } \\
\text { issues of urban food assistance." (p. 153) }\end{array}$ & $\begin{array}{l}\text { News reports } \\
\text { Semi-structured } \\
\text { interviews }\end{array}$ \\
\hline Foley, 2005 [68] & Australia & $\begin{array}{l}\text { "describe urban Indigenous food practices two } \\
\text { centuries after colonization." (p. 25)* }\end{array}$ & $\begin{array}{l}\text { Ethnography } \\
\text { (observation) }\end{array}$ \\
\hline Foley, 2010 [69] & Australia & $\begin{array}{l}\text { “... reports on ethnographic study of urban } \\
\text { Aboriginal family food and implications for } \\
\text { nutrition promotion." (p. 268)* }\end{array}$ & $\begin{array}{l}\text { In-depth interviews } \\
\text { Participant observation }\end{array}$ \\
\hline Ford et al., 2012 [70] & Canada & $\begin{array}{l}\text { "Reports on a baseline study conducted with users } \\
\text { of community food programs in Iqaluit, Nunavut, } \\
\text { to identify and characterize utilization and } \\
\text { document their food security experience." (p. 464) }\end{array}$ & $\begin{array}{l}\text { Survey } \\
\text { Open-ended } \\
\text { interviews } \\
\text { Key informant } \\
\text { interviews }\end{array}$ \\
\hline $\begin{array}{l}\text { Kerpan et al., } \\
2015[71]\end{array}$ & Canada & $\begin{array}{l}\text { "... purpose of this qualitative study was to } \\
\text { examine the determinants of diet for urban } \\
\text { Aboriginal youth with specific emphasis on } \\
\text { culture." (p. 393) }\end{array}$ & $\begin{array}{l}\text { Participatory methods, } \\
\text { with individual } \\
\text { interviews, participant } \\
\text { observation and } \\
\text { informal conversations }\end{array}$ \\
\hline $\begin{array}{l}\text { Lardeau et al., } \\
\quad 2011[72]\end{array}$ & Canada & $\begin{array}{l}\text { "this article describes the results of the application } \\
\text { of Photovoice research methodology among users } \\
\text { of community food programs in Iqaluit, Nunavut, } \\
\text { to develop a baseline understanding of those } \\
\text { factors that affect their own food security status at } \\
\text { an individual level." (p. 3) }\end{array}$ & Photovoice \\
\hline $\begin{array}{l}\text { Mundel and } \\
\text { Chapman, } \\
2010 \text { [73] }\end{array}$ & Canada & $\begin{array}{l}\text { "... case study of a health promotion project, the } \\
\text { Urban Aboriginal Community Kitchen Garden } \\
\text { Project in Vancouver, Canada, which, guided by } \\
\text { the teachings of the Medicine Wheel, aims to } \\
\text { provide culturally appropriate health promotion } \\
\text {...." (p. 166) }\end{array}$ & $\begin{array}{l}\text { Participant observation } \\
\text { Interviews }\end{array}$ \\
\hline Tam et al., 2014 [74] & Canada & $\begin{array}{l}\text { "... a closer examination of coping strategies } \\
\text { among food insecure households in urban and } \\
\text { rural settings in Canada. This includes a } \\
\text { comparative analysis of the role of social networks, } \\
\text { institutional resources, and diet modifications as } \\
\text { strategies to compensate for parent-reported child } \\
\text { hunger using national sources of data ...." (p. 463) } \\
* *\end{array}$ & Survey \\
\hline $\begin{array}{l}\text { Zurba et al., } \\
2012[75]\end{array}$ & Canada & $\begin{array}{l}\text { "... presents the initial outcomes of our } \\
\text { investigation into the deeper sociocultural issues } \\
\text { relating to food security (for a healing group that } \\
\text { included Métis and Aboriginal people living in the } \\
\text { Winnipeg North End)." }\end{array}$ & $\begin{array}{l}\text { Community Food } \\
\text { Security Assessment, } \\
\text { consisting of focus } \\
\text { groups and key } \\
\text { informant interviews }\end{array}$ \\
\hline
\end{tabular}

*: Purpose of the study was not directly focused on food security; **: Purpose did not focus exclusively on Indigenous people. 


\section{Findings from the Literature}

The literature review clearly showed that, in all three nations, food security is generally a concern for urban Indigenous populations. Food security, according to the findings, is a complex issue among urban Indigenous people involving a complicated web of economic, social, cultural, and health considerations. The findings highlight both the variety of experiences of urban Indigenous peoples within and across the three nations, and the commonalities of their experiences. Table 2 outlines the five main themes and related findings from each article.

Table 2. Articles cited by theme.

\begin{tabular}{|c|c|}
\hline Theme & Articles Cited \\
\hline Affordability of and Access to Store Foods & $\begin{array}{l}\text { Abbott et al., } 2010 \\
\text { Adams et al., } 2012 \\
\text { Brown et al., } 2008 \\
\text { Cuesta-Briand et al., } 2013 \\
\text { Dillinger et al., } 1999 \\
\text { Fazzino and Loring, } 2009 \\
\text { Foley, } 2005 \\
\text { Foley, } 2010 \\
\text { Kerpan et al., } 2015 \\
\text { Lardeau et al., } 2013\end{array}$ \\
\hline Dietary Change and Store Foods & $\begin{array}{l}\text { Abbott et al., } 2010 \\
\text { Adams et al., } 2012 \\
\text { Brown et al., } 2008 \\
\text { Fazzino and Loring, } 2009 \\
\text { Foley, } 2005 \\
\text { Foley, } 2010 \\
\text { Tam et al., } 2014 \\
\text { Zurba et al., } 2012\end{array}$ \\
\hline Traditional Foods & $\begin{array}{l}\text { Adams et al., } 2012 \\
\text { Brown et al., } 2008 \\
\text { Cidro et al., } 2015 \\
\text { Elliott et al., } 2012 \\
\text { Fazzino and Loring, } 2009 \\
\text { Foley, } 2005 \\
\text { Ford et al., } 2012 \\
\text { Kerpan et al., } 2015 \\
\text { Lardeau et al., } 2013\end{array}$ \\
\hline Food Sharing, Communal Preparation and Eating & $\begin{array}{l}\text { Brown et al., } 2008 \\
\text { Cidro et al., } 2015 \\
\text { Elliott et al., } 2012 \\
\text { Foley, } 2005 \\
\text { Foley, } 2010 \\
\text { Ford et al., } 2012 \\
\text { Kerpan } \text { et al., } 2015 \\
\text { Lardeau et al., } 2011 \\
\text { Tam et al., } 2014\end{array}$ \\
\hline Food Programming & $\begin{array}{l}\text { Abbott et al., } 2010 \\
\text { Adams et al., } 2012 \\
\text { Cidro } \text { et al., } 2015 \\
\text { Dillinger et al., } 1999 \\
\text { Elliott et al., } 2012 \\
\text { Foley, 2010 } \\
\text { Ford et al., } 2012 \\
\text { Lardeau et al., } 2011 \\
\text { Mundel and Chapman, } 2012 \\
\text { Tam et al., } 2014\end{array}$ \\
\hline
\end{tabular}




\subsection{Affordability of and Access to Store Foods}

A major focus of many of the papers was the affordability of and access to market based foods-foods that are sold in stores such as supermarkets or small grocers and are a part of the industrial food system. In all three countries, for those Indigenous people operating under budget constraints, healthy foods from supermarkets were often unaffordable $[60,61,64,65,68,71]$. In the Australian context, Foley [68] found that despite the breadth of choices in the food system, the cost of healthy food remained a barrier for many urban Indigenous households. The cost of food was the key determinant of food purchases $[60,64]$, and choices were made based on what was on sale at the time [69]. People were reluctant to experiment with new and different foods because they did not want to risk wasting food if it was going to be rejected by household members [69]. In particular, there was concern about the possibility of food wastage by children who rejected new foods [61].

In Canada and the United States, the concerns regarding the affordability of healthy foods depended on the perspective and the location of the study. From the perspective of Indigenous people moving from reserves to urban centres, Brown et al. [50] found that Indigenous people remarked on the lower cost of healthy foods, including fruits, vegetables, and fresh milk. In a study in Alaska, United States, Fazzino and Loring [67] noted that rural residents came to urban centres specifically to purchase store foods, often in bulk, as they were less expensive than in rural and remote locations. Similarly, a rural-urban comparison in California by Dillinger et al. [65] showed that although prices were a concern in urban Sacramento, rural residents faced higher prices for store-bought food. In the Canadian Arctic city of Iqaluit, Nunavut, Lardeau et al. [72] found that high prices for market based foods in store, combined with limited incomes and unemployment, led to extremely high rates of food insecurity.

The need to balance food purchasing with other financial obligations was also a common issue. For example, unexpected fluctuations in the cost of living such as high winter hydro bills, reduced the amount of income available for food purchases. In Australia, Foley [68] shows that among some urban Indigenous people "balancing food costs with other financial commitments are persistent themes" (p. 36). Foley found that people often used food as part of a larger strategy to negotiate monthly household costs. For instance, food may be prioritized over needed medication but not over rent, and people tended to purchase food that was filling rather than nutritious [68]. In Canada, Kerpan et al. [71] had similar findings when speaking with urban Indigenous youth, who stated income was the greatest barrier to healthy food purchasing.

Related to the affordability of market-based food, was the issue of access. Again, this depended on perspective and location. For recent arrivals from reserves, shopping in the urban centre was considered more convenient; stores were open longer hours and with more locations to choose from than on-reserve [62]. Cuesta-Briand et al. [64] in Perth, Australia, noted that many Indigenous health clinic clients had to rely on others for food provisions because of lack of access to a car, no driver's license, or mobility issues. Kerpan et al. [71] noted that for youth living in low-income neighborhoods, a lack of a grocery store nearby meant that youth had to either walk or take public transit to supermarkets, or instead purchased fast-food and processed food from local fast-food outlets and convenience stores.

\subsection{Dietary Change and Store Foods}

Dietary change among urban Indigenous people was examined from various perspectives, including short-term change as people migrated between urban and rural spaces [67], more stable change as people moved from reserve to the city [62], and historical changes over time [68]. Indigenous people with links to both urban and rural/remote/reserve environments discussed having a different diet when residing in the city (called "city foods" by one research participant) vs. when they were in their home communities ("good foods") [67]. Brown et al. [62] found that a move to an urban centre from the reserve led to dietary modifications that included the greater consumption of fast foods, fruits, and vegetables, and a decline in the consumption of traditional or wild foods. 
Dietary choices around fast food were linked to food security in a number of ways. One dietary change that was widely discussed was the prevalence of fast foods in urban Indigenous diets. Definitions of what constituted fast foods were not disclosed in most studies and therefore may vary across studies. Fast foods were eaten because they were considered to be more affordable and accessible than other healthier alternatives $[60,61,68,71]$, or were easier to access in low-income neighbourhoods [71]. Brown et al. [62] noted that for Indigenous people moving from reserves to urban centres, the combination of greater availability of fast foods and a faster paced life resulted in less time to cook, which led to the greater consumption of fast food. However, some people viewed this shift as positive vis-à-vis food access on-reserve, where food was less available and affordable. One study discussed the importance of the link between unhealthy food choices and emotional ties to certain foods, and family belief systems around food for those who are food insecure [75].

Tam and colleagues [74] found that a decrease in food intake, including skipping meals, was an informal coping mechanism among food insecure urban Indigenous parents and children. Food reduction strategies to cope with food insecurity and hunger were higher among those living in urban areas than rural and proposed explanations for this included differences in social support networks and barriers to food access such as proximity to food outlets [74]. Zurba et al. [75] found that all of the participants in their study were concerned with drug and alcohol addiction for youth in their community, and the relationship between addiction and healthy eating.

From a historical perspective, the theft of land, conditions of poverty, government policy, and food rationing have shaped current food practices and preferences $[60,68]$. Foley [68] provided insight into current urban Indigenous food culture in Australia using a post-colonial lens. She states that current foodways among Indigenous people combined those foods considered "traditional colonial" foods and colonial traditions (Sunday dinner together) with recipes handed down from their mothers and grandmothers. Meals such as meat and potatoes, squash, and roasts have become "traditional" foods among many Indigenous people in Australia, despite the colonial origins of these foods [68].

\subsection{Traditional Foods, Knowledge and Skills}

Much of the work done in urban contexts focuses on the role that traditional foods play in Indigenous diets and in potentially alleviating food insecurity [62,63,66-70,72]. Cidro et al. [63] make the argument that food security for Indigenous peoples in urban environments should be addressed through improving Indigenous Food Sovereignty (IFS). Access to traditional foods for Indigenous people in urban contexts promotes health and wellbeing $[63,66,68]$, and is related to cultural learning $[63,71]$. In some studies, Indigenous people express a strong desire to eat traditional foods $[63,66,71,72]$, including in one Canadian case study, a population of urban youth [71]. The hunter-gatherer heritage of Indigenous peoples is a source of pride [71], and some continue to practice activities such as fishing [61].

Access to traditional foods may be problematic, however, for many urban Indigenous people $[62,63,66,68]$. Challenges regarding accessing traditional foods were identified as the distance from reserve or disconnect with family who are not in the urban area [66,72], a loss of skills required to acquire and process traditional foods [66], and the emphasis on the monetary culture in the city $[62,66]$ which also serves to reduce food sharing practices. The results from one study differed notably, in that participants (youth at an Indigenous high school) did have strong food-sharing networks that provided traditional foods, and the prioritization of traditional foods for these youth is credited to both family and school influence [71].

In some communities, traditional foods are not widely available even for purchase [68]. While in urban Australia, there has been a resurgence of "bush tucker" (traditional food) as "exotic" foods among non-Indigenous people; this market is directed towards tourists and not urban Indigenous residents. Even though "bush tucker" is not accessible to many Indigenous Australians due to the exorbitant costs (for example high end restaurants), it is a source of pride for urban Indigenous people [68]. 
Finally, some studies with youth in both Canada and Australia who have been raised in the city show they may not possess the knowledge, skills, or predilection for traditional foods $[63,66,68]$. There is a concern that urban environments have led to de-skilling among Indigenous youth [73]. Youth are trying to balance urban living with traditional values and learning, may have little opportunity to learn traditional food skills and knowledge $[63,66]$, and may be geographically separated from their territories [68]. For some youth, experiences with traditional foods are limited, and Indigenous community events may be the only means through which youth experience traditional foods [68]. However, work by Kerpan et al. [71] shows that for youth who have both family experience preparing and eating traditional food, as well as the influence of Indigenous programming at school, traditional food was an important part of their diet. Cidro et al. [63] stressed the importance of intergenerational connections in order to ensure food knowledge and culture is passed on.

\subsection{Food Sharing, Communal Preparation and Eating}

Food security cannot be disassociated from the context of food culture which, for many Indigenous peoples, includes practices of sharing, preparation, and eating [63]. The value of food-sharing is important for many different Indigenous nations and cultures and promotes community and social cohesion, as well as physical and emotional health and well-being [63,66,68,70-72,74]. Hospitality and welcoming people through sharing meals is important, even if that dinner is based on store-bought rather than traditional foods [68]. Stretching meals even when food is scarce to include guests is a highly valued skill among many urban Indigenous Australians [69].

Food-sharing includes a range of practices from communal preparation and eating to the physical redistribution of food (traditional or market-based) within communities and among family members. Individuals and households sometimes acquire traditional foods through family and friends living in rural and remote areas $[63,67,68]$ because the cost of purchasing traditional foods is often prohibitive in the city $[67,68]$. However, food sharing in regards to traditional and market-based foods continues to be less prevalent among urban Indigenous people when compared to those living rurally or remotely $[62,66,74]$. One study notes that bartering around food and knowledge transactions is common, as it was closer to a relationship of reciprocity around food than a commercial transaction [63]. Food sharing is also used as a coping strategy to deal with food insecurity in urban settings [74]. Multiple studies found that there was a need to strengthen food redistribution, especially of traditional foods through specific programs directed at facilitating the prevalence of food sharing $[62,70,74]$. In contrast, Kerpan et al. [71] found strong food-sharing in their study, including to address food insecurity, and noted that "these methods of food procurement by urban Aboriginal peoples might be rooted in the ways of their ancestors" (p. 396).

\subsection{Food Programming}

There are various food programs that cater to or are accessed by Indigenous people, including: cooking programs [60,69]; supplemental food programs [61,65]; emergency food programs [70-72]; innovative healing programs [75]; gardening and eating programs [63,66,73]; and school food programs [71]. For households forced to rely on supplemental and emergency food programs, concern was expressed about the quality and quantity of the food provided [65,71], and that children raised on foods from food banks and other food provisioning sources may develop unhealthy food preferences [65]. Some Indigenous households relied on supplemental and emergency programs for the majority of their food $[65,70]$, and one study found urban Indigenous people accessed emergency food services more often than on-reserve and rural Indigenous [74]. In part, the latter could be a function of the unavailability of emergency food programs on many reserves.

A common theme was the importance for food programs to be culturally appropriate and consider existing social, political, economic, and gender power dynamics. In one study, participants appreciated supports for healthy eating, but considering the history of Indigenous colonization, certain approaches that were authoritarian or paternalistic led to resistance and/or lowered self-esteem on the part of 
the participants [69]. Users of community food programs may show a preference for Indigenous run programs over non-Indigenous options available in the community [70]. As noted by a program organizer in Mundel and Chapman [73] (p. 170) "there needs to be culturally appropriate programming of this sort, for Indigenous people, not just, okay here's a model and let's invite Indigenous people". Due to the "cultural specific beliefs and behaviours" that they found among their research participants, Kerpan et al. [71] note that programming for urban Indigenous youth cannot be designed from general research conducted among the non-Indigenous population. Zurba et al. [75] noted that the nutrition-emotion nexus of food security needs and gender aspects of food issues need to be better incorporated into programming. The link between food programming and IFS was noted in two studies [63,73], with the latter noting that good food programs can empower Indigenous people, increase capacity, reconnect people with cultural practices, and may even facilitate the decolonization process and make food sovereignty possible.

\section{Discussion}

Although the literature review examined three nations, all with over $50 \%$ of the Indigenous population living in urban areas, there were only 16 total articles that met the review criteria. The lack of urban Indigenous health studies has been noted in the academic literature, and the reasons given for this gap may also explain why there are so few urban Indigenous food security studies [76,77]. Richmond and Big-Canoe [77] state that the absence of urban Indigenous health studies in Canada is a reflection of "a lack of awareness of this rapidly growing pattern of urbanization, though it also reflects public policy discussions centred on the reserve-based population" (p. 229). In Australia, Eades and colleagues [76] postulate that the lack of research on urban Indigenous health could be due to a number of factors, including: the absence of any geographical boundaries in cities that separate Indigenous peoples from the general population; a prioritization of isolated Indigenous populations because their needs are perceived as more pressing than urban Indigenous people and, because of the similarities between the experience of urban Indigenous people and other disadvantaged groups living in urban areas. It may also mean that the popular perception that Indigenous people are tied to the land and bound by reserves is so strong that it precludes the dominant society from imagining Indigenous people outside of those spaces. In her study Penelope Edmonds found that the "presence of Indigenous peoples in settler colonial cities has often been erased from the historical consciousness" [78] (p. 6).

Of particular note, there was a marked lack of studies in the United States. In spite of a search that was broadened to include specific tribe names for each tribe with a population over 100,000 there were only two studies that met the inclusion criteria in the United States. In New York City, the city with the highest urban Indigenous people population in the United States $(111,749$ in 2010), Indigenous people represented only $1.4 \%$ of the total population [19]. A brief scan of the literature revealed that there is a wealth of literature that examines food security among other racialized and ethnic populations (including African Americans and Hispanic Americans), suggesting that the focus of urban food security research has been on other marginalized and disadvantaged populations in the United States rather than Indigenous people.

The literature review also revealed that most of the studies used qualitative methods, which allowed for an in-depth understanding of personal experiences. The use of qualitative methods reflects an effort to forefront the experiences and voices of Indigenous people. Some authors noted the purposeful use of methods that were meaningful to, and respectful of, the local Indigenous community (e.g. [61,66,72,73]). Yet, a qualitative approach poses some limitations, notably, the reliance on small sample sizes. There is a need for more research that looks at the broader picture of urban food security among Indigenous peoples to identify trends and patterns, and to provide longitudinal data. This includes work that isolates certain sub-groups (e.g., single parents, elders, multi-family households, etc.) that may be more vulnerable to food insecurity, as well as identifies specific urban centres (such as Toronto, New York, etc.) or neighbourhoods within cities, to better focus research and food programming needs. There were a few notable studies in the literature search that provided a 
macro-level analysis, suggesting the data may be available if researchers choose to specifically examine urban populations. One study that looked at broader trends focused on Victoria, the most highly populated state in Australia [5]. However, the study failed to differentiate between urban and regional findings (notably, in the city of Melbourne), making it difficult to find and highlight areas of particular need. Another large population study of "off-reserve" Indigenous peoples in Canada [79], made no distinction between urban and rural Indigenous experiences. Urban and rural/reserve spaces offer different challenges for its Indigenous populations, access to nutritious food, food affordability, and service delivery are all necessary elements for consideration.

Although the literature has paid significant attention to historical shifts in the dietary patterns of Indigenous people that were a function of the arrival of Europeans, participation in the fur trade, forced settlement on reserves, and the erosion of access to land- and water-based food sources, comparatively little attention has been paid to how the diets of Indigenous people have changed as a function of increasing urbanization since World War II. This is surprising in light of the fact that more than 50\% of the Indigenous people currently lives in urban areas in Canada, the United States, and Australia. Such an omission is startling particularly in consideration of the disproportionately higher rates of ill health and chronic disease experienced by Indigenous peoples living in cities [63], the ongoing and growing discussions of Indigenous self-determination, and the importance of Indigenous Food Sovereignty (IFS) in addressing the challenges faced by Indigenous people. As Cidro et al. observes "By re-situating Indigenous people's relationship to food by returning to the ceremony of food production, processing, and consumption, by celebrating the gift of food as a part of a larger reciprocal arrangement with the land, Indigenous Food Sovereignty can become more operational, particularly in an urban, Aboriginal context" [63] (p. 15).

The relationship between food security and the concept of IFS, as discussed by Cidro et al. [63], was not prominent in the extant literature. Cidro et al. [63] notes that there is little known about IFS in an urban Canadian context, and indeed we found this to be true in all of the countries included under this scoping review. IFS is based on the premise that food security is not sufficient, but should address unequal power relations and that people must be reconnected to their food systems, with the recognition that food is sacred; people can actively participate in their food system; Indigenous people have the right to self-determination; and there is the need for supportive legislation and policy [32]. This concept has been incorporated into at least one national Canadian organization's policy on Indigenous food [80]. The importance of IFS to food security for Indigenous peoples has been noted in a rural and remote context by Rudolph and McLachlan [81], who state that "the discourse surrounding the northern food crisis needs to move beyond food security to the more important dialogue around Indigenous sovereignty" (p. 1095). However, Cidro et al. [63] cautions that the conditions for IFS in urban environments are different for various reasons, including a different relationship to the land, urban influences on diet, and food skills, and these differences must always be considered. Many Indigenous people have had their connections to their communities and traditional lands severed through historical and ongoing policies and programs that actively or passively promote assimilation. Perhaps a shift from food security to food sovereignty and the focus of IFS on restructuring/reorienting power relationships and structures would help address some of the past and present injustices.

A more complete understanding of urban food security requires better understanding of the connections between urban/rural experiences of Indigenous people. For instance, Indigenous urbanization can be "characterized by high levels of mobility between reserve and urban areas" [82] (pp. 5-6). In northern Canada in particular there are high levels of movement between service centres and reserves. Thus, the urban/rural boundary is a false one in many instances. Urban Indigenous food security involves actors and activities in urban, rural, on-reserve, and/or remote environments. Yet, the linkages and flows of food and money among these places are not well understood. Fazzino and Loring [67] observe that the urban food environment is an important source of market-based foods for rural residents, who often come to the city to buy staple foods in bulk. Food flows between the urban 
(often store foods) and the rural, on-reserve, or remote spaces (a combination of store and traditional foods), and the impact of these movements and linkages are a key area for future research.

\section{Conclusions}

Despite the high number of Indigenous peoples living in urban centres in Australia, Canada, and the United States, there is a paucity of literature on urban Indigenous food security. As a result, it is difficult to ascertain the breadth or depth of understanding required to design effective approaches, programs, and policies that meet the diverse needs of Indigenous households, communities and peoples in various urban locations. In the discussion above, we noted a few avenues of research that are critical for a more complete understanding of urban Indigenous food security, and, thus, should be explored. However, because of the lack of an adequate knowledge base on this important topic, researchers should be open to other pressing research needs that may be identified by Indigenous communities, as our understanding of urban Indigenous food security deepens. Due to the complexity of this topic, we advocate for an intersectional approach including an analysis of race, class, ethnicity, and space for a more complete understanding of food insecurity and, most importantly, the empowerment of Indigenous peoples and communities to determine their own needs and ways forward.

Acknowledgments: This study was funded by a Social Sciences and Humanities Research Council (SSHRC) Insight Development Grant, the Lakehead University Research Chair program, and a Canadian Institutes of Health Research (CIHR) postdoctoral fellowship.

Conflicts of Interest: The authors declare no conflict of interest.

\section{References and Notes}

1. Skinner, K.; Hanning, R.M.; Tsuji, L.J.S.; Hanning, R.M.; Tsuji, L.J.S. Prevalence and severity of household food insecurity of First Nations people living in an on-reserve, sub-Arctic community within the Mushkegowuk Territory. Public Health Nutr. 2014, 17, 31-39. [CrossRef] [PubMed]

2. Skinner, K.; Hanning, R.M.; Desjardins, E.; Tsuji, L.J.S. Giving voice to food insecurity in a remote Indigenous community in subarctic Ontario, Canada: Traditional ways, ways to cope, ways forward. BMC Public Health 2013, 13, 427. [CrossRef] [PubMed]

3. Robidoux, M.A.; Batal, M.; Imbeault, P.; Seabert, T.; Blais, J.M.; Pal, S.; Kruemmel, E.M.; Haman, F. Traditional foodways in two contemporary northern First Nations communities. Can. J. Native Stud. 2012, 32, 59-77.

4. Sebastian, T.; Donelly, M. Policy influences affecting the food practices of Indigenous Australians since colonization. Aust. Aborig. Stud. 2013, 213, 59-75.

5. Markwick, A.; Ansari, Z.; Sullivan, M.; Mcneil, J. Social determinants and lifestyle risk factors only partially explain the higher prevalence of food insecurity among Aboriginal and Torres Strait Islanders in the Australian state of Victoria: A cross-sectional study. BMC Public Health 2014, 14. [CrossRef] [PubMed]

6. Gundersen, C. Measuring the extent, depth, and severity of Food Insecurity: An application to American Indians in the USA. J. Popul. Econ. 2008, 21, 191-215. [CrossRef]

7. White, L.; Stauss, J.H.; Nelson, C.E. Healthy families on American Indian reservations: A summary of six years of research by Tribal College faculty, staff, and students. Am. Indian Cult. Res. J. 2006, 30, 99-114. [CrossRef]

8. Socha, T.; Zahaf, M.; Chambers, L.; Abraham, R.; Fiddler, T. Food security in a northern First Nations community: An exploratory study on food availability and accessibility. J. Aborig. Health 2012, 8, 5-14.

9. Chan, H.M.; Fediuk, K.; Hamilton, S.; Rostas, L.; Caughey, A.; Kuhnlein, H.; Egeland, G.; Loring, E. Food security in Nunavut, Canada: Barriers and recommendations. Int. J. Circumpolar Health 2006, 65, 416-431. [CrossRef] [PubMed]

10. Pal, S.; Haman, F.; Robidoux, M.A. The costs of local food procurement in two northern Indigenous communities in Canada. Food Foodways 2013, 21, 132-152. [CrossRef]

11. Egeland, G.M.; Johnson-Down, L.; Cao, Z.R.; Sheikh, N.; Weiler, H. Food insecurity and nutrition transition combine to affect nutrient intakes in Canadian Arctic communities. J. Nutr. 2011, 141, 1746-1753. [CrossRef] [PubMed] 
12. Kuhnlein, H.V.; Receveur, O.; Soueida, R.; Egeland, G.M. Arctic Indigenous peoples experience the nutrition transition with changing dietary patters and obesity. J. Nutr. 2004, 134, 1447-1453. [PubMed]

13. Haman, F.; Fontaine-Bisson, B.; Batal, M.; Imbeault, P.; Blais, J.M.; Robidoux, M.A. Obesity and type 2 diabetes in Northern Canada's remote First Nations communities: The dietary dilemma. Int. J. Obes. 2010, 34, S24-S31. [CrossRef] [PubMed]

14. Willows, N.D.; Veugelers, P.; Raine, K.; Kuhle, S. Associations between households food insecurity and health outcomes in the Aboriginal population (excluding reserves). Health Rep. 2011, 22, 15-20. [PubMed]

15. Ford, J.D.; Beaumier, M. Feeding the family during times of stress: Experience and determinants of food insecurity in an Inuit community. Geogr. J. 2011, 177, 44-61. [CrossRef] [PubMed]

16. Lambden, J.; Receveur, O.; Marshall, J.; Kuhnlein, H.V. Traditional and market food access in Arctic Canada is affected by economic factors. Int. J. Circumpolar Health 2006, 65, 331-340. [CrossRef] [PubMed]

17. Socha, T.; Zahaf, M.; Chambers, L.; Abraham, R.; Fiddler, T. Food availability, food store management, and food pricing in a northern community First Nation community. Int. J. Humanit. Soc. Sci. 2011, 1, $49-61$.

18. Aboriginal Peoples in Canada in 2006: Inuit, Métis and First Nations, 2006 Census. Available online: http:/ /www12.statcan.ca/census-recensement/2006/as-sa/97-558/pdf/97-558-XIE2006001.pdf (accessed on 16 March 2016).

19. The American Indian and Alaska Native Population: 2010. Available online: http://www.census.gov/ prod/cen2010/briefs/c2010br-10.pdf (accessed on 16 March 2016).

20. Estimates of Aboriginal and Torres Island Strait Islander Australians. Available online: http:/ / www.abs.gov.au/ausstats/abs@.nsf/mf/3238.0.55.001 (accessed on 16 March 2016).

21. Hill, G.; Cooke, M. How do you build a community? Developing community capacity and social capital in an urban Aboriginal setting. Pimatisiwin 2013, 11, 421-432.

22. Cooke, M.; Mitrou, F.; Lawrence, D.; Guimond, E.; Beavon, D. Indigenous well-being in four countries: An application of the UNDP's human development index to Indigenous peoples in Australia, Canada, New Zealand, and the United States. BMC Int. Health Hum. Rights 2007, 7. [CrossRef] [PubMed]

23. Mitrou, F.; Cooke, M.; Lawrence, D.; Povah, D.; Mobilia, E.; Guimond, E.; Zubrick, S.R. Gaps in Indigenous disadvantage not closing: A census cohort study of social determinants of health in Australia, Canada, and New Zealand from 1981-2006. BMC Public Health 2014, 14. [CrossRef] [PubMed]

24. Bussey, C. Food security and traditional foods in remote Aboriginal communities: A review of the literature. Aust. Indig. Health Bull. 2013, 13, 1172-1187.

25. Clifford, A.; McCalman, J.; Bainbridge, R.; Tsey, K. Interventions to improve cultural competency in health care for Indigenous peoples of Australia, New Zealand, Canada and the USA: A systematic review. Int. J. Qual. Health Care 2015, 27, 89-98. [PubMed]

26. Glover, M.; Kira, A.; Johnston, V.; Walker, N.; Thomas, D.; Chang, A.B.; Bullen, C.; Segan, C.J.; Brown, N. A systematic review of barriers and facilitators to participation in randomized controlled trials by Indigenous people from New Zealand, Australia, Canada and the United States. Glob. Health Promot. 2014. [CrossRef] [PubMed]

27. Anderson, J.T.; Collins, D. Prevalence and causes of urban homelessness among Indigenous peoples: A three-country scoping review. Hous. Stud. 2014, 29, 959-976. [CrossRef]

28. Rome Declaration on World Food Security and World Food Summit Plan of Action. Available online: http:/ /www.fao.org/docrep/003/w3613e/w3613e00.htm (accessed on 16 March 2016).

29. Willows, N. Determinants of healthy eating in Aboriginal peoples in Canada: The current state of knowledge and research gaps. Can. J. Public Health 2005, 96, 32-36.

30. Power, E. Conceptualizing food security for Aboriginal people in Canada. Can. J. Public Health 2008, 99, 95-97. [PubMed]

31. Martin, D. Nutrition Transition and Public-Health Crisis: Aboriginal Perspectives on Food and Eating. In Critical Perspective in Food Studies; Oxford University Press: Oxford, UK, 2012; pp. 208-222.

32. Morrison, D. Indigenous Food Sovereignty: A Model for Learning. In Food Sovereignty in Canada: Creating Just and Sustainable Food Systems; Wiebe, N., Desmarais, A.A., Wittman, H., Eds.; Fernwood Publishing: Halifax, NS, Canada, 2011; pp. 97-111.

33. Gurney, R.M.; Caniglia, B.S.; Mix, T.L.; Baum, K.A. Native American food security and traditional foods: A review of the literature. Sociol. Compass 2015, 9, 681-693. [CrossRef] 
34. Caspi, C.E.; Sorensen, G.; Subramanian, S.; Kawachi, I. The local food environment and diet: A systematic review. Health Place 2012, 18, 1172-1187. [CrossRef] [PubMed]

35. Measuring the Food Environment in Canada. Available online: http://www.hc-sc.gc.ca/fn-an/nutrition/ pol/som-ex-sum-environ-eng.php (accessed on 16 March 2016).

36. Household Food Insecurity in Canada, 2012. Available online: http://nutritionalsciences.lamp.utoronto.ca/ just-released-household-food-insecurity-in-canada-2012/ (accessed on 16 March 2016).

37. First Nations Food, Nutrition \& Environment Study. Available online: http://www.fnfnes.ca/ (accessed on 16 March 2016).

38. Norris, M.J.; Clatworthy, S. Urbanization and migration patterns of Aboriginal populations in Canada: A half century in review (1951 to 2006). Aborig. Policy Stud. 2011, 1, 13-77. [CrossRef]

39. Aboriginal Peoples in Canada: First Nations People, Métis, and Inuit. Available online: https://www12. statcan.gc.ca/nhs-enm/2011/as-sa/99-011-x/99-011-x2011001-eng.cfm (accessed on 16 March 2016).

40. Acheampong, I.; Haldeman, L. Are nutrition knowledge, attitudes, and beliefs associated with obesity among low-income Hispanic and African American women caretakers? J. Obes. 2013, 2013, 123901. [CrossRef] [PubMed]

41. Brunst, K.J.; Wright, R.O.; Digioia, K.; Enlow, M.B.; Fernandez, H.; Wright, R.J.; Kannan, S. Racial/ethnic and sociodemographic factors associated with micronutrient intakes and inadequacies among pregnant women in an urban US population. Public Health Nutr. 2013, 17, 1960-1970. [CrossRef] [PubMed]

42. Chilton, M.; Booth, S. Hunger of the body and hunger of the mind: African American Women's perceptions of food insecurity, health and violence. J. Nutr. Educ. Behav. 2007, 39, 116-125. [CrossRef] [PubMed]

43. Dammann, K.W.; Smith, C. Race, homelessness, and other environmental factors associated with the food-purchasing behavior of low-income women. J. Am. Diet. Assoc. 2010, 110, 1351-1356. [CrossRef] [PubMed]

44. Firth, J. Healthy choices and heavy burdens: race, citizenship, and gender in the obesity epidemic. J. Int. Women's Stud. 2012, 13, 33-51.

45. Laraia, B.A.; Borja, J.B.; Bentley, M.E. Grandmothers, fathers, and depressive symptoms are associated with food insecurity among low-income first-time African-American mothers in North Carolina. J. Am Diet. Assoc. 2009, 109, 1042-1047. [CrossRef] [PubMed]

46. Nackers, L.M.; Appelhans, B.M. Food insecurity is linked to a food environment promoting obesity in households with children. J. Nutr. Educ. Behav. 2013, 45, 780-784. [CrossRef] [PubMed]

47. USDA Economic Research Service-Key Statistics and Graphics in 2014. Available online: http:/ / www.ers.usda.gov/topics/food-nutrition-assistance/food-security-in-the-us/key-statistics-graphics .aspx (accessed on 16 March 2016).

48. The Termination Act severed the relationship between Native American Tribes and the federal government by terminating the status of tribes as legal entities and giving states authority over their land and resources. Ponchetti, H.D. Fractured relations at home: The 1953 termination act's effect on Tribal relations throughout Southern California Indian country. Am. Indian Q. 2009, 33, 427-439.

49. Secondbite: Food for People in Need. Available online: http://secondbite.org/ (accessed on 16 March 2016).

50. Browne, J.; Laurence, S.; Thorpe, S. Acting on food insecurity in urban Aboriginal and Torres Strait Islander communities. Available online: http://www.healthinfonet.ecu.edu.au/health-risks/nutrition/ reviews/other-reviews (accessed on 16 March 2016).

51. Grimshaw, J. A Guide to Knowledge Synthesis: A Knowledge Synthesis Chapter. Available online: http:/ /www.cihr-irsc.gc.ca/e/41382.html (accessed on 16 March 2016).

52. Arksey, H.; O’Malley, L. Scoping studies: Towards a methodological framework. Int. J. Soc. Res. Methodol. 2005, 8, 19-32. [CrossRef]

53. Levac, D.; Colquhoun, H.; O’Brien, K.K. Scoping studies: Advancing the methodology. Implement. Sci. 2010, 5. [CrossRef] [PubMed]

54. Weeks, J.R.; Jurgens, C. Defining Urban Areas. In Remote Sensing of Urban and Suburban Areas; Springer: Berlin/Heidelberg, Germany, 2010; pp. 33-45.

55. Who Are Indigenous Peoples? Available online: http://www.un.org/esa/socdev/unpfii/documents/ 5session_factsheet1.pdf (accessed on 16 March 2016). 
56. Bartlett, J.G.; Madariaga-Vignudo, L.; O'neil, J.D.; Kuhnlein, H.V. Identifying Indigenous peoples for health research in a global context: A review of perspectives and challenges. Int. J. Circumpolar Health 2007, 66, 287-307. [CrossRef] [PubMed]

57. Kuhnlein, H.V. Promoting the nutritional and cultural benefits of traditional food systems of Indigenous people. J. Nutr. 2003, 56, 222-223.

58. Kuhnlein, H.; Erasmus, B.; Creed-Kanashiro, H.; Englberger, L.; Okeke, C.; Turner, N.; Allen, L.; Bhattacharjee, L. Indigenous peoples' food systems for health: Finding interventions that work. Public Health Nutr. 2006, 9, 1013-1019. [CrossRef] [PubMed]

59. Ryan, R. Cochrane Consumers and Communication Review Group: Data Synthesis and Analysis. Available online: http:/ /cccrg.cochrane.org/sites/cccrg.cochrane.org/files/uploads/AnalysisRestyled.pdf (accessed on 16 March 2016).

60. Abbott, P.; Davidson, J.; Moore, L.; Rubinstein, R. Barriers and enhancers to dietary behavior change of Aboriginal people attending a diabetes cooking course. Health Promot. J. Aust. 2010, 21, 33-38.

61. Adams, K.; Burns, C.; Liebzeit, A.; Ryschka, J.; Thorpe, S.; Browne, J. Use of participatory research and photo-voice to support urban Aboriginal healthy eating. Health Soc. Care Community 2012, 20, 497-505. [CrossRef] [PubMed]

62. Brown, J.; Isaak, C.; Lengyel, C.; Hanning, R.; Friel, J. Moving to the city from the reserve: Perceived changes in food choices. Pimatisiwin 2008, 6, 1-16.

63. Cidro, J.; Adekunle, B.; Peters, E.; Martens, T. Beyond food: Understanding access to cultural food for urban Indigenous people in Winnipeg as Indigenous food sovereignty. Can. J. Urban Res. 2015, 24, $24-43$.

64. Cuesta-Briand, B.; Saggers, S.; McManus, A. "You get the quickest and the cheapest stuff you can": Food security issues among low-income earners living with diabetes. Aust. Med. J. 2011, 4, 683-691. [CrossRef]

65. Dillinger, T.; Jett, S.; Martha, M. Feast or famine? Supplemental food programs and their impacts on two American Indian communities in California. Int. J. Food Sci. Nutr. 1999, 50, 173-187. [PubMed]

66. Elliott, B.; Jayatilaka, D.; Brown, C.; Varley, L.; Corbett, K.K. "We are not being heard": Aboriginal perspectives on traditional foods access and food security. J. Environ. Public Health 2012, 2012, 130945. [CrossRef] [PubMed]

67. Fazzino, D.V.; Loring, P.A. From crisis to cumulative effects: Food security challenges in Alaska. NAPA Bull. 2009, 32, 152-177. [CrossRef]

68. Foley, W. Tradition and change in urban Indigenous food practices. Postcolon. Stud. Cult. Polit. Econ. 2005, 8, 25-44. [CrossRef]

69. Foley, W. Family food work: Lessons learned from urban Aboriginal women about nutrition promotion. Aust. J. Prim. Health 2010, 16, 268-274. [CrossRef] [PubMed]

70. Ford, J.; Lardeau, M.-P.; Vanderbilt, W. The characteristics and experience of community food program users in Arctic Canada: A case study from Iqaluit, Nunavut. BMC Public Health 2012, 12. [CrossRef] [PubMed]

71. Kerpan, S.T.; Humbert, M.; Henry, C.J. Determinants of diet for urban Aboriginal youth implications for health promotion. Health Promot. Pract. 2015, 16, 392-400. [CrossRef] [PubMed]

72. Lardeau, M.P.; Healey, G.; Ford, J. The use of photovoice to document and characterize the food security of users of community food programs in Iqaluit, Nunavut. Rural Remote Health 2013, 11, 1680-1697.

73. Mundel, E.; Chapman, G.E. A decolonizing approach to health promotion in Canada: The case of the urban Aboriginal community kitchen garden project. Health Promot. Int. 2010, 25, 166-173. [CrossRef] [PubMed]

74. Tam, B.; Findlay, L.; Kohen, D. Social networks as a coping strategy for food insecurity and hunger for young Aboriginal and Canadian children. Societies 2014, 4, 463-476. [CrossRef]

75. Zurba, M.; Islam, D.; Smith, D.; Thompson, S. Food and healing: An urban community food security assessment for the North End of Winnipeg. Urban Res. Pract. 2012, 5, 284-289. [CrossRef]

76. Eades, S.J.; Bailey, S.; Williamson, A.B.; Craig, J.C.; Redman, S. The health of urban Aboriginal people: insufficient data to close the gap. Med. J. Aust. 2010, 193, 521-524. [PubMed]

77. Richmond, C.; Big-Canoe, K. The Social Determinants of Aboriginal Health: Defining a Research Agenda for Canada's Urban Population. In Aboriginal Policy Research: Urban Perspectives; Thompson Educational Publishing: Toronto, ON, Canada, 2013; pp. 227-241.

78. Edmonds, P. Urbanizing Frontiers: Indigenous Peoples and Settlers in 19th-Century Pacific Rim Cities; UBC Press: Vancouver, BC, Canada, 2010. 
79. Willows, N.D.; Veugelers, P.; Raine, K.; Kuhle, S. Prevalence and sociodemographic risk factors related to household food security in Aboriginal peoples in Canada. Public Health Nutr. 2008, 12, 1150-1156. [CrossRef] [PubMed]

80. Some organizations and scholars identify the vital links between traditional foods, culture, and food security as central to food sovereignty. For example, Food Secure Canada (a national food advocacy organization) in a discussion paper stated that traditional foods in urban centres in Canada are important because in "urban areas deprived of traditional foods, we experience food deserts, extreme hunger, and the onset and entrenchment of preventable disease" and recommends action towards food sovereignty. Indigenous Food Sovereignty: Discussion Paper 1. Available online: http:/ / foodsecurecanada.org/sites/foodsecurecanada.org/files/DP1_Indigenous_Food_Sovereignty.pdf (accessed on 16 March 2016).

81. Rudolph, K.R.; McLachlan, S.M. Seeking Indigenous food sovereignty: Origins of and responses to the food crisis in northern Manitoba, Canada. Local Environ. 2013, 19, 1079-1098. [CrossRef]

82. Senese, L.C. Exploring Gendered Relationships between Aboriginal Urbanization, Aboriginal Rights and Health. Master's Thesis, University of Toronto, Toronto, ON, Canada, 2011.

(C) 2016 by the authors; licensee MDPI, Basel, Switzerland. This article is an open access article distributed under the terms and conditions of the Creative Commons by Attribution (CC-BY) license (http://creativecommons.org/licenses/by/4.0/). 